\title{
Research on Problems and Countermeasures of Application-oriented Marketing Innovation and Entrepreneurship Education
}

\author{
Zhang Yunming \\ Guizhou University of Finance and Economics, Guiyang, Guizhou, China, 550004
}

Keywords: marketing; innovation and entrepreneurship education; problems

\begin{abstract}
The application-oriented marketing innovation and entrepreneurship education is of profound significance to the discipline construction. The practice teaching of field marketing course can cultivate the students' innovative and entrepreneurial ability, and the teaching effect directly affects the effectiveness of college students' innovation and entrepreneurship. But in reality, there are still some problems, such as ideas, teaching staff and implementation contents. Its influence is shown in how to deal with the relationship between professional learning and innovation, how to find a perfect system to support the implementation, and how to scientifically evaluate the problems. This paper analyzes the main problems in the innovation and entrepreneurship marketing education, and puts forward the application type of marketing specialty combined with characteristics of marketing personnel training, and solutions to cultivate innovation and entrepreneurship marketing talents.
\end{abstract}

\section{Introduction}

With the rapid and rapid development of China's economy, the demand for marketing talents is also increasing. The marketing profession has always been a hot professional for employment. According to relevant data, marketing professionals have consistently topped the list in employment rankings in recent years. With the constant improvement and development of the market, society has increasingly demanded the ability and quality of marketing professionals, not only satisfying the ability to sell products, but also requires innovative and entrepreneurial compound marketing talents, who can provide comprehensive services [1]. However, at present, the marketing students cultivated by local universities in China are generally lack of practical ability, innovation and entrepreneurship, and they are severely disconnected from the needs of companies for marketing professionals, and cannot meet the needs of the society for marketing talents. Therefore, how to integrate innovation and entrepreneurship knowledge into the cultivation of marketing professionals and improve marketing professionals' practical ability and innovation and entrepreneurship is an urgent issue for us. And it is necessary to speed up the reform of the training model for marketing professionals and cultivate innovative entrepreneurial marketing talents that are suitable for the needs of enterprise development.

\section{The Status Quo of Application-oriented Marketing Innovation and Entrepreneurship Education}

\subsection{The unclear concept of innovation and entrepreneurship education}

It is manifested as lack of research on the concept of innovation and entrepreneurship education, unable to systematically lead the practice of innovation and entrepreneurship education. Many teachers and students think that they do not have the resources and conditions for innovation and entrepreneurship, and lack the motivation to participate in innovation and entrepreneurship.

\subsection{Lack of systematic plan for innovation and entrepreneurship education}

The research of marketing and applied innovation and entrepreneurship education shows that innovation and entrepreneurship education emphasizes teaching materials, teachers are more classroom-oriented, and actual content is missing. Basically it is not related to practice, and it is far 
from student expectations. This fully shows that innovation and entrepreneurship education urgently needs to do top-level design.

\subsection{The weak construction of a qualified teacher team for innovation and entrepreneurship education}

The instructors with entrepreneurial ideas and entrepreneurial skills are seriously inadequate. Most of the innovation and entrepreneurship education courses involving colleges and universities in the investigation are served by teachers of the ideological and political course department. They both lack the basic theories of business operations and have little entrepreneurial experience at the same time. Although teachers in economic management majors participate in innovation and entrepreneurship education in some colleges and universities, they also face the same problems. Some colleges have uneven levels of external instructors hired, and most of them cannot summarize and improve their entrepreneurial experiences theoretically.

\subsection{Lack of actual practice}

Innovation and entrepreneurship education practice activities are more often involved in various entrepreneurial competitions. The level of student innovation and entrepreneurship practice is very low, and the value of practical achievements is relatively low, which has limited help for students.

\section{Problems and Challenges of Application-oriented Marketing Innovation and Entrepreneurship Education}

\subsection{Training objectives of innovation and entrepreneurship divorced from training objects}

Innovation and entrepreneurship education is a gradual process, with innovation and entrepreneurship initiation stage, innovation and entrepreneurship training stage and innovation and entrepreneurship stage [2]. At present, the training of innovative and entrepreneurial talents has not been classified and directed according to the differences of students. For some students who are ready to start a business, innovative and entrepreneurial education is a must, for most students, innovative and entrepreneurial education is a booster for overall improvement of quality, which should run through the whole process of training the whole talent.

\subsection{Low conversion rate of innovation and entrepreneurial achievements}

There are no shortages of outstanding works in various innovation and entrepreneurship projects organized by colleges and universities. However, schools have not established effective linkage mechanisms with enterprises in providing innovation and entrepreneurship services, which has resulted in the loss of commercial opportunities for some project achievements, making the low conversion rate of the achievements of innovation and entrepreneurship projects in reality.

\subsection{The backward evaluation mechanism of innovation and entrepreneurship education}

The evaluation of the work of the teachers engaged in innovative and entrepreneurial education has a wide range of emphasis on academic research, neglecting the teaching link, and attaching importance to the teaching of professional knowledge, ignoring the cultivation of the students' accomplishment, especially the professional accomplishment, paying attention to the number of qualified students and neglecting the quality of the standard. At the same time, the evaluation of students' acceptance of innovation and entrepreneurship education only focuses on examination scores and practical operation.

\subsection{Lack of perfect institutional support in innovation and entrepreneurship education}

Application-oriented marketing innovation and entrepreneurship education is currently viewed simply as a trend of teaching methods. It is not yet realized that this is a systematic project and must be synchronized from the aspects of renewal of ideas, reflection of systems, and practical aspects. Firstly, the current semester management system is not conducive to the development of innovation 
and entrepreneurship education. The design of the semester system must fully consider the study rules of students, and also consider the specific environmental factors in the local area. The current marketing application-oriented setting of the current science still follows the semester setting of traditional college education, and the semester is generally longer than it should be. Although this arrangement is conducive to student's systematic learning, it has lost its rigidity in teaching arrangements and has hindered students' self-study and practice.

Secondly, the current credit system is not conducive to the development of students' potential for innovation and entrepreneurship. At present, the credit system requires excessively high requirements for students' graduation credits, which makes it difficult for students to have the possibility of independent study. Students' elective credits account for a small proportion of their total credits, and students have difficulty in choosing their own choices. Even if students are allowed to choose their time, the range of choices is extremely limited. The flexible learning system is in a form that is not conducive to the emergence of outstanding students with individuality.

\section{Countermeasures to Build the Application-oriented Marketing Innovation and Entrepreneurship Education System}

\subsection{Clearly cultivate goals}

The training target for marketing professionals should be changed from advanced specialized talents to application-oriented talents. For the marketing profession, applied talents are specialized talents who can apply the theoretical knowledge and skills they have learned to practice [3]. The essential feature of applied talents is that in addition to having a solid theoretical knowledge, they should also have certain skills, that is, have clear professionalism and practicality. The reform of practice teaching in marketing courses should aim at cultivating the ability of innovation and entrepreneurship for undergraduates. It should be based on cultivating talents with solid marketing theory, high innovation literacy, and entrepreneurial potential. It must focus on this goal to formulate practical teaching plans and determine teaching mode. In determining the specific training arrangements and training requirements of the market analysis and marketing strategy, the major marketing knowledge sectors should also be considered and weighed from the perspective of cultivating innovative entrepreneurial ability.

\subsection{The principle of adaptability}

Marketing is one of the general management courses offered by colleges and universities in China. Although many colleges and universities have opened the course of marketing, the teaching facilities, teaching sites, teachers and training bases are different in various schools, and the origin and quality of students in various colleges and universities are different, even in the same University, The training objectives and curriculum structure of different professions are different. Therefore, when designing the curriculum practice teaching plan and choosing the curriculum practice teaching mode, it should be set according to the orientation of the school, the goal of training the talents, the specialty and the development of the subject.

\subsection{The principle of integrity}

The cultivation of student marketing practice and innovation and entrepreneurship requires a practical syllabus or teaching plan, while at the same time evaluating the effectiveness of the outline or plan. Theoretical teaching and practical teaching are indispensable for marketing course teaching. It is necessary to coordinate the relationship between theoretical teaching and practical teaching, balance the ratio between theoretical teaching and practical teaching in a limited time, and comprehensively measure theoretical teaching, and the effect of practical teaching to ensure the integrity of marketing teaching courses.

\subsection{Multi-stage case teaching}


Case teaching method is one of the most commonly used methods for practical teaching of marketing courses. It can help students internalize theoretical knowledge, cultivate innovative spirit, improve the quality of innovation, and develop the ability to solve practical problems. However, some teachers did not fully play the role of case teaching in order to activate the classroom atmosphere and intersperse some cases during the class. Therefore, in order to ensure the teaching effect, we can adopt the method of multi-stage case teaching to carry out practical teaching. In the implementation of the "multi stage case teaching" process, teachers should pay attention to the quality of case control and prevent students from copying other people's compiling cases. After the case discussion, the teachers need to summarize and comment, while linking the marketing theory knowledge, inspire students' innovative thinking and stimulate students' sense of innovation and entrepreneurship.

\subsection{Three-dimensional project teaching}

The integration of innovation, entrepreneurship education and curriculum teaching needs to be guided by the ideas, methods and capabilities of innovation and entrepreneurship education to optimize the teaching of recombination practice and the content of practical teaching that is matched with it. The most effective method is to carry out project teaching. The project teaching method refers to the teaching and practice activities that teachers and students perform together to complete a complete project. The practice teaching of marketing courses oriented to the cultivation of innovation and entrepreneurship is in urgent need of three-dimensional project teaching.

\subsection{Multi-level discipline competition}

Colleges and universities can carry out multi-level academic competitions based on their own positioning, school resources and professional characteristics [4]. Such as teaching class competitions, intramural competitions, and off-campus competitions, to develop the competition among teams, fully stimulating the students' enthusiasm for participation, and allowing the students to gradually develop self-learning during the competition, and then cultivate students' innovative spirit.

\subsection{Improve the teaching and evaluation criteria}

In order to standardize the teaching workload of teachers, it should reestablish the diversified teaching workload norms including classroom teaching, extracurricular innovation and entrepreneurial practice guidance, guidance of graduation thesis, practice and so on, and encourage teachers to participate in scientific research and entrepreneurial practice.

\subsection{Expand the practice teaching base outside school}

In order to better cultivate marketing talents for innovation and entrepreneurship, according to the direction of various marketing professions, it should establish practice bases in cooperation with enterprises respectively, and innovate practice training modes to organize students to participate in special activities for corporate marketing. At the same time, experts from the company's practice areas should be hired to participate in marketing professional education, special lectures, and internship guidance, so as to established a strong cooperation faculty team.

\section{Summary}

Innovation and entrepreneurship education is a new requirement put forward by the development of quality education in the new era. It is an inevitable trend for marketing professionals to make timely adjustments. In order to adhere to the cooperation and development, the marketing major should be guided by the promotion of employment and entrepreneurship, keep pace with the times, pay attention to the training of students' innovative and entrepreneurial skills in the training program of the professional talents, and continue to develop new ideas in training ideas, teaching methods and teaching means, and strengthen the training of students' practical application ability and the 
promotion of comprehensive quality, so as to cultivate high level applied marketing talents with innovative and practical ability for the society.

\section{References}

[1] Liu Yanjun. Exploration and Practice of Innovation and Entrepreneurship Education in Local Universities: Taking Huanghuai University as an Example[J]. Vocational and Technical Education,2015(12), p.48

[2] Zhou Xiaoyong. Research on Marketing Practice Teaching Evaluation System Based on Innovation and Entrepreneurial Orientation[J]. Heilongjiang Journal of Animal Husbandry and Veterinary,2016(8), p.199

[3] Liu Wei. Thoughts on the Construction of Innovative Talent Training System in Colleges and Universities[J]. Education Science, 2011, 27(5), p.64

[4] Wang Zhanren, the system structure and theoretical value of broad-spectrum innovation and entrepreneurship education [J]. Education Research, 2015, (5), p.56 